Review

\title{
LAKE ENGURE CATCHMENT AREA AS AN EXAMPLE OF THE INTERACTION OF NATURAL CONDITIONS, SETTLEMENT PATTERN AND ECONOMIC ACTIVITIES
}

\author{
Ivars Strautnieks and Ineta Grīne \\ Faculty of Geography and Earth Sciences, University of Latvia, Alberta iela 10, Riga 1010, LATVIA \\ E-mail: Ivars.Strautnieks@lu.Iv, Ineta.Grine@Iu.Iv
}

Communicated by Māris Kḷaviṇš

\begin{abstract}
The authors have written this paper as an overview of the area, which includes earlier published data and the results of a new, original research. It covers the geological structure, including a characterisation of the geology of the Sub-Quaternary surface. Described in greater detail are the Quaternary cover and the surface relief, as well as the hypsometry, which in many locations directly influence the conditions of surface drainage, soil development and landscape characteristics. Based on the morphology and internal structure of the relief, the main stages in the formation of the relief are also outlined, in effect marking temporal differences in landscape development. The influence of these factors, as well as a string of other natural factors (groundwater and surface drainage, the proximity of the sea) within distinct parts of the study area, explain the character of human economic activities, the development of settlement and the traditions that have continued over the centuries. Several different areas are clearly distinguishable in functional terms: 1) the area where farming is the characteristic activity, 2) the area used for fishing and recreation, 3) forested areas, with soils unsuitable for agriculture. The form and intensity of land use also determine the distribution of settlements and population size.
\end{abstract}

Key words: geological structure, relief, landscape, settlement pattern.

\section{INTRODUCTION}

The research included in this review paper on the Lake Engure catchment area, which examines the interaction between natural conditions, settlement pattern and economic activities, was undertaken in the frame of the project "Development of a conceptual model for assessing the impact of socio-economic factors on biodiversity in a long-term model area in Latvia". The Lake Engure catchment area was chosen as a case study area for integrated multidisciplinary research. The authors' aim was not only to characterise the geological structure and surface relief of the area and outline the main stages in the development of the landscape, but also to show how the natural conditions have determined human economic activities, the settlement pattern and traditions. The information reflected in the article may be useful for research in other disciplines and for regional planning.

\section{SOURCES OF INFORMATION}

Several sources of information have been used in order to characterise the relief, landscape and natural conditions in the study area, as well as the settlement structure. The main sources are cartographic material (topographical maps at scales $1: 10000,1: 25000$ and $1: 75000$, satellite maps at scale 1 : 50000 and orthophotos, as well as geological maps, maps of the pre-Quaternary geology, the subQuaternary surface and Quaternary deposits, and a map of natural areas) along with published statistical data. Material obtained in the course of fieldwork were also used: the depositional conditions of deposits forming the relief were studied at exposures, the genetic types of deposits were determined and their lithological characteristics assessed, in order to ascertain more precisely the distribution of genetic types of relief forms and their reflection in the landscape. The fieldwork also included photographic documentation and interviews with local residents. Internet resources were also used as sources for the study: databases and publications on settlements and natural sites in the Lake Engure catchment area.

Spatial analysis and preparation of cartographic material was conducted using the GIS software ESRI ArcView 10. Maps were created using various kinds of cartographic material, including data layers from Corine Land Cover 2000 and Envirotech GIS Latvija 9.2.mdb. 


\section{GEOGRAPHICAL POSITION AND HYPSOMETRY}

Lake Engure is one of Latvia's largest lakes $\left(41.3 \mathrm{~km}^{2}\right)$ and the very largest in the Coastal Lowland. The lake, about $2-5 \mathrm{~km}$ wide, stretches parallel to the west coast of the Gulf of Riga for $17 \mathrm{~km}$, being separated from the gulf by a belt of land that is generally $1.2-2.8 \mathrm{~km}$ wide. It is one of the relict lagoonal lakes of the Littorina Sea, and thus multidisciplinary research provides important information about present-day geological processes in the area, geological history, biological diversity, human impact, landscape changes, overall palaeogeographic development during the postglacial period etc. Lake Engure is not an isolated hydrological feature, but rather constitutes a significant component (low point) of the hydrological system of the Lake Engure catchment area (Fig. 1).

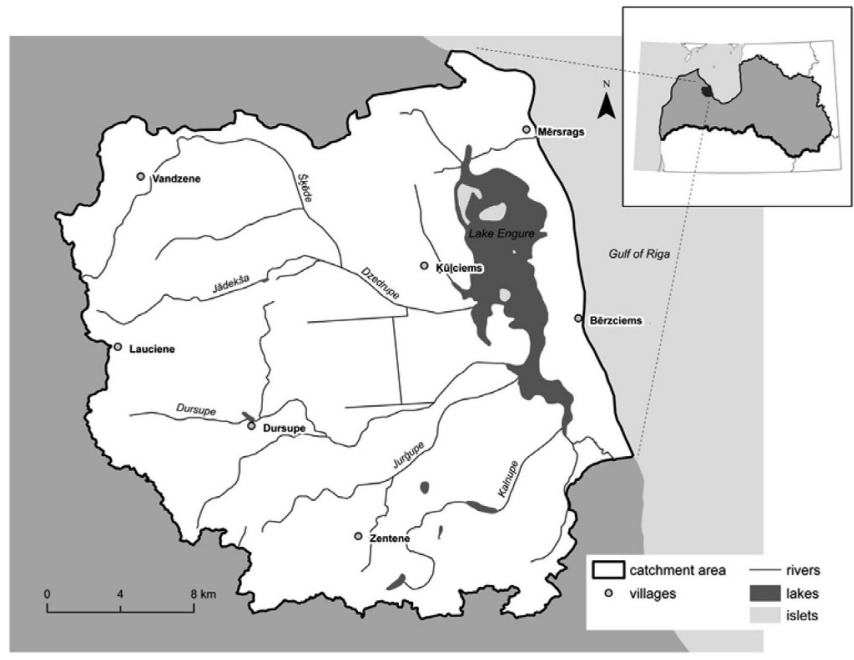

Fig. 1. Location of the Lake Engure catchment area (prepared by authors using the map database GIS Latvija 9.2 (SIA Envirotech)).

The Lake Engure catchment area covers an area of about $644 \mathrm{~km}^{2}$. Six rivers flow into the lake: the Dzedrupe, Dursupe, Pelčupe, Jurğupe, Kalnupe and Melnupe (Placēna, 1995). The largest river of the Lake Engure catchment area, the 28-km-long River Dursupe, enters the southern part of the lake. In its course through the Vanema Hilly Area, the river flows through agricultural land, whereas on the Engure Plain it crosses a forested area. The other rivers (Dzedrupe, Jurğupe and Melnupe) flow mainly through forested areas. The limits of the Lake Engure catchment area are defined by the surface drainage watershed that can be traced along the highest points in the relief. The highest points of the watershed are in the western part of the catchment area, where they reach a height of 100-120 m a.s.l., with a maximum of 156.5 m (Bākkalns Hill) in the Talsi or Aklaisciems Massif, $7 \mathrm{~km}$ south of Lauciene. Because human activities have a significant and very direct impact on the environment and landscapes, the study area is actually slightly larger than the above-described extent of the catchment. Thus, the study also covers the area north of the town of Mērsrags, which lies outside the Lake Engure catchment area, as well as the village of Engure, which, although very close to Lake En- gure, is nevertheless outside the lake catchment. The study area also includes the belt of land between Engure and Mērsrags, where the highest relief forms the watershed between the Lake Engure catchment area and the coastal catchment area of the Baltic Sea (Gulf of Riga). Along this belt the watershed coincides approximately with the highest dunes between the Gulf of Riga and Lake Engure, which means that there is a marked asymmetry in the relief and in the separation of surface drainage in the area between Engure and Merrsrags. The eastern slope of this belt is narrower and relatively steeper, with shorter watercourses (coastal catchment area of the Gulf of Riga), while the western slope is wider and more gently sloping, with longer watercourses (Lake Engure catchment area).

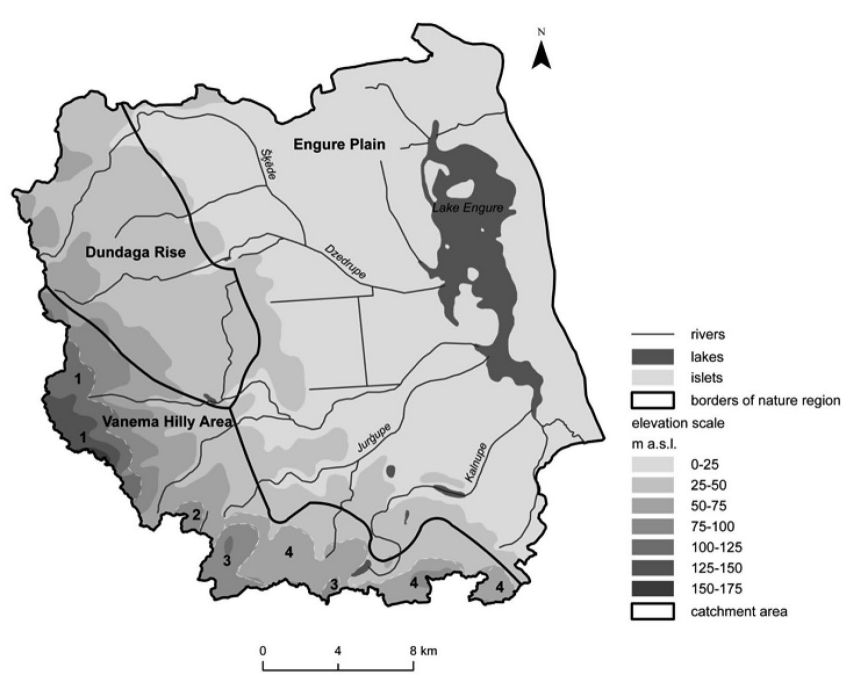

Fig. 2. Hypsometry of the Lake Engure catchment area. In the map: 1 - the Aklaisciems massif, 2 - the Cēre megadrumlin, 3 - Rauda composite ridge, 4 - Plien,i composite ridge (prepared by authors using the map database GIS Latvija 9.2 (SIA Envirotech)).

The study area includes two nature regions (Fig. 2), the differences between them generally being very clearly perceptible visually as one moves from west to east. The eastern part of the area (17-20 km wide) is located in the Engure Plain of the Coastal Lowland, where the elevation varies in the range of 0-5 $\mathrm{m}$ a.s.l. to $12-25 \mathrm{~m}$ a.s.l. The western part of the Lake Engure catchment area (5-10 km wide) is located within the Vanema Hilly Area of the Northern Kursa Upland, where the height of the relief generally varies in the range of 30-60 $\mathrm{m}$ a.s.l. in the hollows and 70-100 $\mathrm{m}$ a.s.l. on the hilltops, up to $120-150 \mathrm{~m}$ in places. The northwestern part of the catchment area is located within the Dundaga Rise, where the height a.s.l. is $35-45 \mathrm{~m}$, reaching $60 \mathrm{~m}$ in the environs of Laidze.

\section{GEOLOGY AND GEOMORPHOLOGY}

Information from survey of earlier research materials and data obtained in field investigations of this study allow to update geology and geomorphology of study area. The natural differences between the Coastal Lowland and the North- 
ern Kursa Upland, including the differences in elevation and relief, reflect the geological structure of the area. Particularly important is the variation in the height of the subQuaternary surface from west to east (Fig. 3A). The Northern Kursa Upland is located on a rise of the sub-Quaternary surface. In the Vanema Hilly Area in the vicinity of the watershed it generally lies at a height of 40-50 m a.s.1., reaching a maximum, 60-70 $\mathrm{m}$ a.s.1., in the environs of Lauciene (Juškevičs, 1999). The surface of the bedrock dips in the direction of the depression of the Gulf of Riga. At the boundary with the Engure Plain it is about $20 \mathrm{~m}$ a.s.l. or even less, and already $10 \mathrm{~km}$ from the coast of the Gulf of Riga it falls below sea level. In the area of the lake itself, the sub-Quaternary surface falls to $10 \mathrm{~m}$ below sea level. The sub-Quaternary surface is dissected by several valley-like incisions, which are not visible in the surface relief, being filled in by younger deposits. They can thus be classified as buried valleys (Fig. 3C). The largest of these occurs between the village of Engure and the eastern shore of the lake, stretching about $12 \mathrm{~km}$ to the south-west. The buried valley is $0.8-1.5 \mathrm{~km}$ wide, the depth of the cut reaching $121 \mathrm{~m}$ below sea level. Another valley-like cut into the bedrock is located by Mērsrags, and stretches to the SSE, approaching close to Lake Engure, thus demonstrating that the boundaries of the surface drainage catchments do not coincide with the boundaries of the groundwater drainage catchments. The overall monoclinal fall of the sub-Quaternary surface in the direction of the Gulf of Riga is interrupted by localised elevations between Lake Engure and the Gulf of Riga (Juškevičs, 1999). The sub-Quaternary surface slopes most steeply on the slope of the Northern Kursa Upland.
There are significant differences between the Engure Plain and the area belonging to the Northern Kursa Upland in terms of the lithology of the Devonian deposits at the pre-Quaternary surface (Fig. 3C). On the Engure Plain the pre-Quaternary surface consists of Devonian terrigenic deposits: mainly sandstones, as well as siltstones and clays in places, belonging to the Gauja Formation. However, at the south-eastern limit of the area there is a belt $3-5 \mathrm{~km}$ wide with Amata Formation sandstones, including clay and siltstone strata (Mūrnieks, 1999). In the southern and south-western part of the Lake Engure catchment area, on the slope of the Northern Kursa Upland, there is a belt 1-2 km wide with a succession of carbonaceous and sulphate deposits. One of these corresponds to the Salaspils Formation, which includes gypsum in addition to dolomites. The sloping surface of the elevation of the sub-Quaternary deposits at the foot of the slope of the Northern Kursa Upland and the succession of different Devonian sedimentary deposits within it influence the discharge of pre-Quaternary groundwater horizons on the Engure Plain and in the overall direction of the Gulf of Riga.

The Devonian bedrock is overlain by a cover of Quaternary deposits, varying in thickness from 6-8 $\mathrm{m}$ up to $10-15 \mathrm{~m}$ on the Engure Plain and the Dundaga Rise, increasing to a thickness of as much as 40-60 $\mathrm{m}$ in the Vanema Hilly Area (Fig. 3B). This difference in thickness reflects the differences in the conditions of formation of the deposits. The greater thickness of deposits in the Vanema Hilly Area is connected with a slowing of the ice flow in front of an escarpment in the pre-Quaternary deposits, leading to the ac-
A

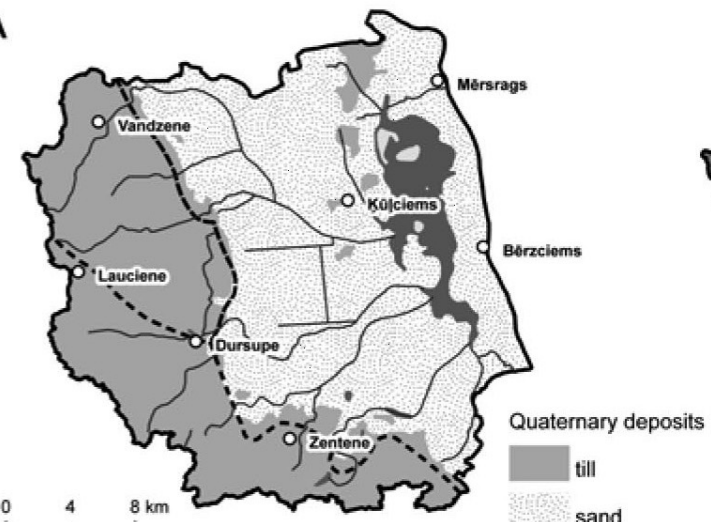

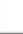

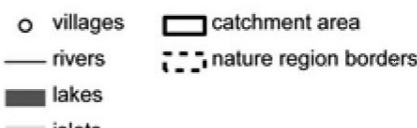

Fig. 3. Geology of the Lake Engure catchment area: A - map of Quaternary deposits; B - relief map of the sub-Quaternary surface; C geological map of the pre-Quaternary surface (prepared by authors using the map database GIS Latvija 9.2 (SIA Envirotech) and geological maps).
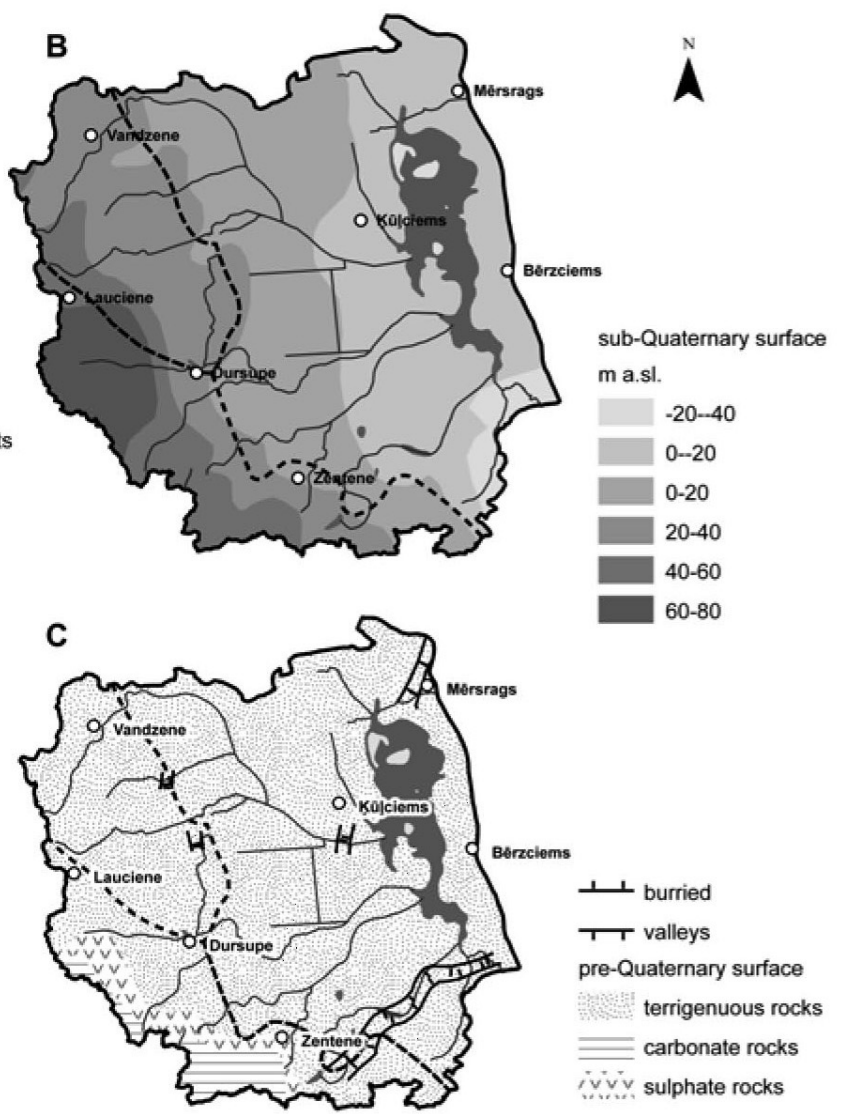
cumulation and deformation of glacigenic and glaciofluvial deposits. The maximum thickness is observed in the valley-like incisions, or buried valleys, filled with Quaternary deposits. Here the thickness reaches 79-135 m (Juškevičs, 1999).

In the Vanema Hilly Area, where the thickness of the Quaternary cover is greatest, the differences in thickness are reflected in the surface relief. In the hills, ranges of morainic hills and other positive landforms, the thickness increases, while in the depressions, including the hollows between hills, it decreases. The morphology of the relief, the degree of surface dissection and elevation are the most characteristic and distinctive features of the Vanema Hilly Area and at the same time of the western part of the Lake Engure catchment area. The Vanema Hilly Area mainly has glacigenic landforms: morainic hills, separate areas of hills and composite ridges of glacigenic landforms, which group together forming several complexes that differ from one another in terms of morphology and orientation in relation to the regional direction of ice movement. Stretching NW-SE for more than $20 \mathrm{~km}$, approximately parallel to one another, are the Rauda and Plieni composite ridges. They are frontally oriented in relation to the ice flow from the direction of the Gulf of Riga during the final phases of the last (Veichselian) glaciation. The Plieñi composite ridge is hypsometrically lower (60-70 m a.s.1.) and lies immediately adjacent to the Engure Plain. The Rauda composite ridge, separated from the Plieni ridge by a linear depression, is at a higher elevation (90-120 m a.s.l.), and the high spots form the watershed of the Lake Engure catchment area. The relative height of individual landforms (hills and ridges) within the two composite ridges reaches $15-25 \mathrm{~m}$, while the height of the slopes in relation to the depression separating the composite ridges, and likewise the height of the slope of the Plieni ridge facing the Gulf of Riga, reaches 40-70 m. The relative height of the slopes and the slope angles of 15-25 ${ }^{\circ} \mathrm{C}$ are significant for the development of the surface drainage pattern, and this is without any doubt one of the factors influencing the landscape and environment within the Lake Engure catchment area as a whole.

Highest in elevation (130-156 m a.s.l.) are the hilltops of the Aklaisciems or Talsi Massif south of Lauciene. The surface of this hilly area generally consists of low, small morainic hills, with isolated long, ridge-like glacigenic hills in places, the relative height of which generally does not exceed 12-15 m. The Aklaisciems Massif is separated from the Dundaga Rise by a very distinct $20-30 \mathrm{~m}$ high ice-contact slope. This marks the boundary between the active ice flows from the direction of the Gulf of Riga and the passive ice in the Aklaisciems Massif (Страуме, 1979; Аболтиньш, 1989; Zelčs et al., 2004).

The Aklaisciems Massif is separated from the Rauda and Plieni composite ridges by a glacial depression formed by the Upper Abava Ice Tongue, within which, above localised elevations in the pre-Quaternary deposits (40-50 m a.s.1.) at Cêre and Oksle, there are parallel ridge-like glacigenic landforms oriented north-south. Based on studies of their inter- nal structure and morphology (Strautnieks et al., 2004; Markots et al., 2007), these ridges with a length of several kilometres $(2-6 \mathrm{~km})$ and a width of $1-3 \mathrm{~km}$ were classified as megadrumlins. They all have an undulating, drumlinised surface formed in subglacial conditions. The largest one, the Cēre Megadrumlin, has a stepped north-facing slope, i.e. facing towards the ice sheet, up to $50 \mathrm{~m}$ high, dissected by erosion, indicating the complex origin of this landform. An esker identified on the top of the Oksle Megadrumlin also reflects the action of meltwater flows at the end of the glaciation. The megadrumlins are separated by $20-40 \mathrm{~m}$ deep linear depressions that reflect the local features of the present-day drainage network, generally falling in the direction of the Gulf of Riga.

The Dundaga Rise is characterised by undulating relief. The undulating surface is created by two perpendicularly oriented systems of ridges. One of these consists of narrow ridges oriented SW-NE, morphologically reminiscent of drumlins. The other system consists of similar landforms oriented NW-SE, but with a broader top and gentler slopes.

A characteristic feature of both the Vanema Hilly Area and the Dundaga Rise is that the uppermost or covering layer consists mainly of sandy-clay or clayey-sand till with pebbles and boulders from the last (Veichselian) glaciation, indicating that it was accumulated in subglacial conditions. In many areas there are large erratic boulders in the till and also at the surface. On the Dundaga Rise the thickness of the till is about 5-7 m (Juškevičs, 1999). Studies on the structure of the relief (Вейнбергс, 1968; Страуме, 1979; Strautnieks et al., 2004; Markots et al., 2007) show that the thickness of the till in the Vanema Hilly Area is very uneven. It varies from $1-1.5 \mathrm{~m}$ at the tops of the positive landforms, disappearing altogether in places, to 3-5 and 10-15 $\mathrm{m}$ on the lower slopes. Sections compiled from geological core data indicate that there is another layer of till, of similar thickness, perhaps dating from the Veichselian Glaciation, in the lower part of the Quaternary cover, directly overlying the Devonian strata (Juškevičs, 1999). Enclosed between the till layers are sandy, gravelly and pebbly layers that have been folded under the pressure of the glacier. The deformed glaciofluvial deposits between the till layers constitute the core of morainic hills and composite ridges, attaining a thickness of $10-20 \mathrm{~m}$ or more. These inter-till deposits constitute major sand and gravel resources, concentrated mainly in the Aklaisciems Massif at Lauciene and on the Cēre Megadrumlin.

A characteristic feature of the eastern part of the Lake Engure catchment, i.e. the Engure Plain, distinguishing it from the western part, is the widespread occurrence of deposits from various stages in the development of the Baltic Sea Basin, which form the upper part of the Quaternary cover. The lower part of the Quaternary cover, directly overlying the Devonian sandstones, consists of Veichselian Glaciation till, 1.5-3 m thick, increasing to a thickness of 4-7 m thick in places. West and north-west of Lake Engure the till is exposed at the surface, forming unusual islands of till with large boulders. The till, being a relatively imperme- 
able layer, plays an important role in shaping the hydrogeological conditions on the Engure Plain. In the western part of the plain the till is overlain by a layer of sandy deposits of the Baltic Ice Lake, 1.5-4 m thick, increasing to a thickness of 6-9 $\mathrm{m}$ in places, laid down in the final stage of the glaciation. Holocene deposits occur in the eastern part of the plain, closer to the Gulf of Riga. The till is overlain by the terrigenic deposits of the Littorina Sea. These generally vary in thickness from 1.5 to $3 \mathrm{~m}$. Within the depression of Lake Engure the Littorina Sea deposits are overlain by limnic sediments. In the belt of land between Lake Engure and the Gulf of Riga the thickness of the Littorina Sea deposits reaches 5-7 m (Juškevičs, 1999), overlain by aeolian deposits, forming ranges of dunes $5 \mathrm{~m}$ or more in thickness, parallel to the long axis of the belt of land. Aeolian depositional landforms also occur in the area of Baltic Ice Lake deposits. Presumably, their distribution is not fortuitous, but relates to one of the shorelines of the Baltic Ice Lake. The relative height of the inland dunes reaches $10-15 \mathrm{~m}$. The highest vertical diversity of Quaternary deposits might occur in the above-mentioned buried valleys, where they reach a thickness of more than $100 \mathrm{~m}$, but so far there is no precise information.

\section{SEQUENCE OF LANDFORMS DEVELOPMENT}

As can be seen from the account given above, the heights above sea level, the relief (and degree of dissection) and the geological structure are the most important factors shaping the nature region and nature areas, and hence also the natural and cultural landscape, and they determine the local differences within the Lake Engure catchment area. However, it should be noted that in the final phase of the Pleistocene glaciation the whole area did not become ice-free simultaneously, and the natural conditions during the Holocene were also significantly different in various parts of the Lake Engure catchment area (Zelčs et al., 2004). This means that both depositional processes, and the development of soils and the landscape itself followed a certain sequence. From the final phase of the glacial up to the present day several stages in the development of the area are distinguished by authors:

1) The Aklaisciems Massif (Fig. 2), at the highest elevation, was the first to start becoming glacier ice-free. This process began with the melting of blocks of passive ice at a time when there were still active ice flows in the adjacent lower-lying areas.

2) Melting of the blocks of passive ice began and continued on the Rauda composite ridge (Fig. 2), while on the Engure Plain and Dundaga Rise, as well as in the depression between the Aklaisciems Massif and the Rauda and Plieni composite ridges (Fig. 2). This means that the development of the megadrumlins at Cēre and Oksle (Fig. 2) was completed in this phase.

3) The Engure Plain (Fig. 2) was the last area to become glacier ice-free.
4) As the passive ice melted, an ice-dammed lake formed, and at about $11.7 \mathrm{ka}$ cal. BP (Andrén et al., 2011) a phase began when the Northern Kursa Upland was ice-free, while the development of the Engure Plain continued on the bed and in the littoral belt of the Baltic Ice Lake. During the time of the Baltic Ice Lake, its level evidently changed, as indicated by former shorelines along which dune ridges can be traced.

5) Following the draining of the Baltic Ice Lake, the Yoldia Sea stage of the Baltic Basin marks the beginning of the postglacial period or Holocene. During the Holocene, along with the climatic changes and the rise and fall of the water level in the Baltic Sea Basin, the Engure Plain experienced transgressions and regressions that occurred in several stages of development of the Baltic Basin. As a result, former shorelines can be traced on the Engure Plain, in the form of belts of sandy marine deposits with dune ridges, as well as areas where the till and boulders exposed at the surface reflect the destructive impact of waves (coastal and bed erosion). Particularly significant for the development of this area was the Littorina Sea stage, $10.5 \mathrm{ka}$ cal. BC (Andrén et al., 2011), which has left fairly widespread deposits in the eastern part of the Engure Plain. It is thought that no less important for the formation of the surface relief of the Engure Plain and the development of the landscapes were the regressional periods between the transgressions, when the water level was lower than the present level of the Baltic Sea, but there is insufficient data on these periods when continental conditions prevailed.

Depending on the lithology, grain size and texture of the deposits dominating in the upper part of the Quaternary cover, as well as the degree of relief dissection, various conditions of surface drainage have developed. Thus, in the Northern Kursa Upland, for example, where relatively impermeable sandy-clay or clayey-sand till predominates, there is greater surface runoff on the slopes of positive landforms, with excess moisture in the closed, poorly-drained hollows. The Coastal Lowland generally have sandy deposits that are more permeable, resulting in more rapid infiltration of precipitation in locations with a higher elevation and producing a deficit of moisture, reducing the volume and intensity of surface drainage. At the same time, conditions of excess moisture form in lower areas under the influence of the groundwater level. The groundwater level is close to the surface because of the low elevation of the Engure Plain above the level of the Baltic Sea and Lake Engure, and the characteristics of the geological structure. Under the influence of these factors, there is discharge of both Quaternary and pre-Quaternary groundwater in the Engure Plain, especially at the foot of the Northern Kursa Upland. Groundwater discharge is indicated not only by the presence of springs and seeps, such as the Galtene Spring, but also by a belt of freshwater lime along the slope of the Northern Kursa Upland. There are major freshwater lime deposits in the environs of Balgale and Zentene, such as Zentenes Liekna. The presence of freshwater lime deposits indicates the high calcium carbonate content of the emerging ground- 
water, which evidently belongs to the Upper Devonian Plavinas and Daugava groundwater horizons, where the main source of carbonates is the till of the Veichselian glaciation. Likewise, the strata of the Salaspils Formation, containing gypsum, which lie close to the surface at Zentene, may be the source of an increased concentration of sulphate ions in the groundwater, as well as in watercourses and waterbodies.

The above account shows that the geological structure, especially the uppermost layer of the Quaternary deposits and the relief, are significant for the overall development of soils and landscapes. It is important to note that the soils are relatively young, and, like the development of the area as a whole, soil development shows a pattern of decreasing age from west to east. This means that the soils on the Northern Kursa Upland are older than those of the Engure Plain, and within the Engure Plain the soils in the area of Baltic Ice Lake deposits are older than those in the belt of Littorina Sea deposits. The youngest soils are those in the belt around Lake Engure, between its present shore and the former (pre-1842) shoreline.

\section{LANDSCAPES, LAND USE, ECONOMIC ACTIVITIES AND SETTLEMENT PATTERN}

The Lake Engure catchment area is one of the most contrasting areas in Latvia, where the influence of the natural conditions on human economic activities and on overall landscape characteristics is very vividly expressed. The natural conditions have always had, and still have, a significant influence on human activities, settlement pattern, land use and economic activities. Landscapes less transformed by human activities are widespread in those areas that have sandy podsol soils unsuitable for farming, or soils that have developed in conditions of excess moisture. Thus, there is an area of coniferous forest on the Engure Plain in the belt between the former shorelines of the Baltic Ice Lake and Littorina Sea. There is a similar belt of coniferous forest between Lake Engure and the Gulf of Riga, interrupted by population centres: Engure, Bērzciems and Mērsrags. It should be noted that the characteristics of the landscape of this belt of land are determined not only by the unsuitability of the soil for agriculture, but also by the fact that the traditional occupation of the residents of the shore of the Gulf of Riga does not involve agriculture. Only the western shore of Lake Engure in the area around Kūlciems and Krievragciems, where the soil parent material in places is sandy-clay till, or where till is to be found very close to the surface, is taken up by arable land and pasture. The drained area west of Lake Engure, between the present lakeshore and the pre-1842 shoreline, is swampy. In order to improve the drainage conditions and enhance the potential for farming, a dense network of drainage ditches has been created on the Engure Plain. Also, all the rivers, apart from the Dursupe, have been channelised.

In order to restrict economic activities and preserve the diversity of animal and plant species, in 1957-1998, Lake
Engure was included in an ornithological restricted area, and in 1988, the Lake Engure Nature Park was established (Fig. 5B). In order to stop the lake overgrowing, wild cattle and horses were introduced into the park, and the lakeshore grasslands are being re-established. Engure Nature Park includes the population centres of Abragciems, Bērzciems and part of Kūḷciems. The area's status as an ornithological restricted area and nature park has meant restrictions on economic and recreational activities (Vìksne, 1995; Anonīms, 2001b; Anonīms, 2011e).

On the other hand, the western part of the Lake Engure catchment area largely consists of a mosaic landscape of agricultural land alternating with forest. Clayey soils are more extensive in the Northern Kursa Upland, and thus mixed and deciduous forest occurs there, while the southernmost part has coniferous and mixed forest (Fig. 4).

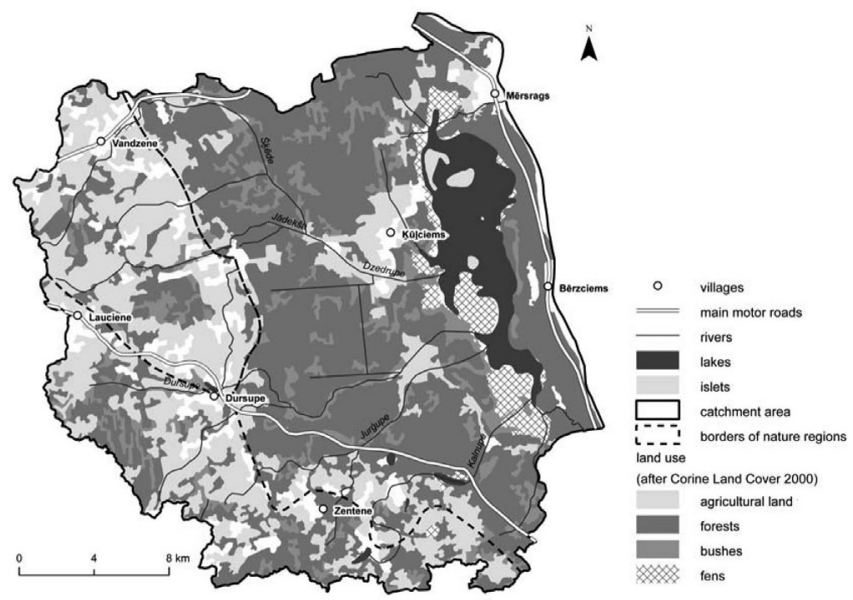

Fig. 4. Land use in the Lake Engure catchment area (prepared by authors using the map database GIS Latvija 9.2 (SIA Envirotech) and Corine Land Cover 2000).

Settlements, representing one of the most important elements making up the cultural landscape, are unevenly distributed in the Lake Engure catchment area, but their distribution is closely related to the above-described natural conditions. Nowadays the settlements in the Coastal Lowland (in the eastern part of the catchment) are concentrated along the northern and western shore of Lake Engure and along the main roads. In the western part of the catchment area (the Northern Kursa Upland) settlements are more evenly distributed, in spite of the fact that the Dundaga Rise is an undulating plain, where ridges with gentle slopes alternate with hollows, while the Vanema Hilly Area has a very pronounced relief, with hills having steeper slopes, separated by hollows. Another characteristic feature is that in the eastern part of the Lake Engure catchment area (the Coastal Lowland) the settlements concentrate around the major local roads along the western shore of Lake Engure and along the road of the Gulf of Riga. In the Vanema Hilly Area and on the Dundaga Rise there are evidently different factors behind settlement location, namely position in the relief, microclimate, proximity to watercourses and the possibility of access to groundwater (Fig. 5B). 
A

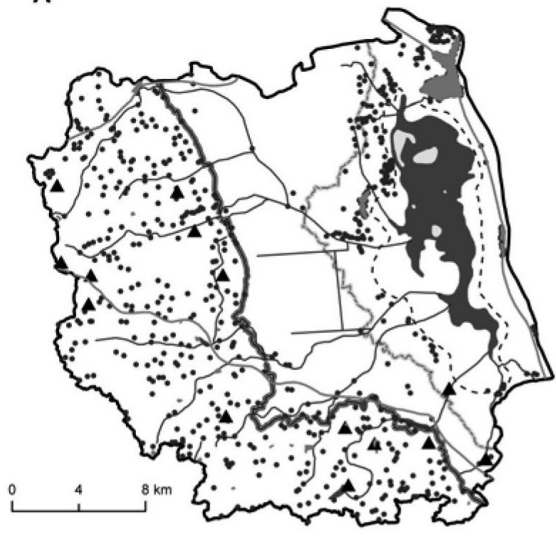

B

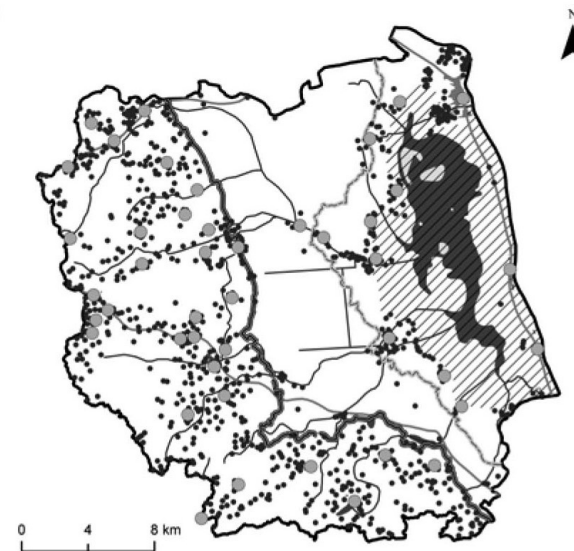

$8 \mathrm{~km}$

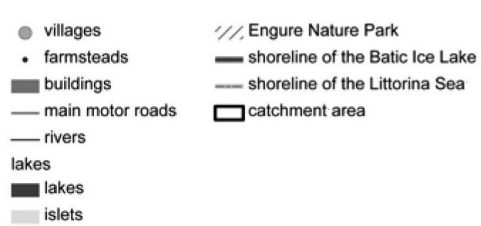

Fig. 5. Settlement structure in the Lake Engure catchment area: $\mathrm{A}$ - at the beginning of the 20th century; B - at the beginning of the 21 st century (prepared by authors using the map database GIS Latvija 9.2 (SIA Envirotech) and topographical maps at scales $1: 75000$, satellite maps at scale 1 : $50000)$.
Analysis by authors of this paper of early 20th century cartographic material shows that the settlement pattern of that time also exhibits the above-mentioned locational characteristics. The settlement structure in rural areas in the early 20th century consisted of single homesteads, manors and villages. The majority of manors were located in the western part of the Lake Engure catchment area, from the western limit of the catchment area up to the former shoreline of the Baltic Ice Lake, corresponding approximately to the foot of the slope of the Northern Kursa Upland. At the beginning of the 20th century, there were single homesteads in the western part of the Lake Engure catchment area and around the northern and western shore of Lake Engure. Fishing villages were located along the coast of the Gulf of Riga. Information about villages engaged in fishing date back to the 16th century. The Lake Engure catchment area includes three fishing villages: Mērsrags, Bērzciems and Abragciems (Fig. 5A). In addition, historical settlements are located along the western shore of Lake Engure, following the former shoreline of the lake (the shoreline from the time before the Mērsrags Canal was dug). The largest are: Dzedruciems, Kū ḷciems and Krievragciems.

According to the analysis of the cartographic material by authors, during the 20th century the number of settlements increased in the vicinity of the major population centres (e.g. around Mērsrags, Vandzene, Iğene and Zentene). During the second half of the 20th century, a large number of homesteads disappeared in areas far from the main roads. As indicated by interviews, nowadays there are few homesteads that have owners; they are uninhabited and abandoned. In addition to these, there are "holiday homes", i.e. homes occupied during summer vacations or on weekends (e.g. in Kūụlciems and Dzedri in Kūụlciems Parish). With the exception of Mērsrags, there is no major housing development taking place within the Lake Engure catchment area.

In the early 20th century, and likewise today, the area between the Baltic Ice Lake shoreline and that of the Littorina
Sea is uninhabited. This area is covered by coniferous forest, which can be explained by the presence of Baltic Ice Lake and wind-borne sands, making the area rather unsuitable for agriculture (Fig. 5).

Today, the largest population centres of the Lake Engure catchment area are three large villages: Mērsrags, Vandzene and Lauciene. According to the statistics, in 2006, Mērsrags had a population of 1800 , or more than $90 \%$ of the total population of Mērsrags civil parish (pagasts), while Vandzene and Lauciene had 601 and 568 residents, respectively, corresponding to $28-30 \%$ of the total parish population (Anonīms, 2007).

It is important to note that the digging of the 4-km-long Mērsrags Canal in 1842 promoted the development of settlements and economic activities. The main aim behind the digging of the canal was to lower the water level of Lake Engure and extend the area of land suitable for agriculture. According to various sources (Placēna, 1995; Anonīms, 2011f), after the canal was dug, the level of Lake Engure fell by $1.5 \mathrm{~m}$, and the western and southern shores of the lake retreated by $0.5-0.8 \mathrm{~km}$, causing changes in the landscape. After the Mērsrags Canal was dug, dunes appeared on the eastern shore, with grasslands forming mainly on the western shore. Some of the wet grasslands became suitable for farming, namely as hay meadows and pasture. Economic activities were still observed there in the 1950s (Anonīms, 2011f; Anonīms, 2011c). Secondly, the digging of the Mērsrags Canal promoted the development of Mērsrags as a population centre: a harbour was built here, along with a lighthouse, and ocean-going ships were built in the shipyard (Anonims, 2011f). Already at the beginning of the 20th century, most of the production facilities in Mērsrags pagasts were concentrated there, and thus the port provided a large number of jobs for the residents of Mērsrags civil parish and the surrounding area. During Latvia's first period of independence, even though it did not obtain the status of a village, Mērsrags was one of the larg- 
est population centres along the coast of the Gulf of Riga (with a population of about 200) (Rutkis, 1960).

The Lake Engure catchment area also includes different areas in terms of economic activity. Historically, a situation developed where economic activity along the coastal belt of the Gulf of Riga was concentrated around fisheries: fishing, fish processing, as well as port services and shipbuilding. Thus, for example, in Mērsrags civil parish the historical, traditional economic activities have been fishing and fish processing. According to the interview materials, nowadays the fish factories employ people from Mērsrags, as well as from Talsi, Sabile and Vandzene. Port services, in the form of goods transportation, have an important place. Because of the transportation of goods through the port and the contribution of EU funding, the port is undergoing modernisation and rapid development (Anonīms, 2002; Anonīms, 2011h; Anonīms, 2011g).

On the other hand, in Kūḷciems civil parish, which is separated from the sea by Lake Engure and by a narrow belt of land, the historically established, traditional activities in the early $20^{\text {th }}$ century were fishing, fish processing, reed-cutting and, in contrast to the coastal civil parish, stock farming as well (Anonims, 2001). According to the interview materials, during the Soviet period, when the small collective farms were merged, the Lā̄čplēsis collective farm was established, which specialised in dairy and pig farming, as well as growing fodder crops, potatoes and carrots. Nowadays the main economic activity of the population is farming. The largest area of land is farmed by SIA Avoti, engaged in livestock farming. The rest of the farms are small, and only use the land to meet their own needs, not keeping any stock, which means that there is land that is not being farmed and is gradually becoming overgrown.

One of the current directions of development in areas along the Baltic Sea coast is tourism, as reflected in the presence of guesthouses, camping places and rest areas. Around Lake Engure there are guesthouses, three boat hire locations and birdwatching towers. In this way the potential for tourism and leisure is being enhanced, and this includes fishing, boating, birdwatching, etc. According to fieldwork materials, in certain locations the new and modern elements contrast with buildings that have lost their functional significance, for example the new buildings in the area around Mērsrags Lighthouse and the remains of the military structures from the Soviet period.

In contrast to the Engure Plain, the main economic activity on the Dundaga Rise and the Vanema Hilly Area today, as at the beginning of the $20^{\text {th }}$ century, is agriculture. For example, agriculture has always been active in Vandzene, with well-developed farms (Vandzenes pagasts, 2002; Anonīms, 2011a). The main branches of agriculture in the civil parish today are cereal cultivation, dairy farming, and horticulture, along with goat farming, beekeeping and timber processing. Nowadays the civil parish has several welldeveloped farms engaged in stock farming, cereal farming and vegetable farming, while the smaller farms are engaged in fruit growing (mainly strawberries and raspberries) and vegetable farming. Also well-developed in the civil parish is timber processing and partly also fish processing, because of the proximity to the sea (the largest company being SIA Senga). Just as in the Soviet period, the civil parish has production companies, as well as service and trading companies.

Major changes in land use took place at the end of the $20^{\text {th }}$ century, along with the abolition of the collective farms, the privatisation of land and subsequent economic processes in the country. These changes are visually very clear in the landscape, when one inspects the area. In the eastern part of the Lake Engure catchment area (the Coastal Lowland) there has been a relative increase in the proportion of unutilised agricultural land. There is unused agricultural land in the vicinity of the major population centres and in the more remote parts of civil parishes (e.g. in Mèrsrags civil parish). On the other hand, in the western part of the Lake Engure catchment area (e.g. in Vandzene and Lauciene civil parish) the proportion of unused farmland is comparatively small, and this occurs mainly in the more remote areas of the civil parishes, although relatively more overgrown agricultural land can be seen in the southern part of the Lake Engure catchment area (e.g., in Zentene civil parish). Thus, there is relatively more unused farmland in the Vanema Hilly Area than on the Dundaga Rise, as has been described by other researchers (Penēze un Krūze, 2011).

In terms of the present-day administrative division, the Lake Engure catchment area includes parts of the counties of Talsi, Tukums, Engure and Mērsrags, as well as a small part of Kandava County (i.e. Balgale, Kūḷciems and Zentene civil parishes, together with large parts of Mērsrags and Lauciene Parishes, parts of Engure and Vandzene Parishes, and very small parts of Strazde, Pūre, Sēme and Cēre Parishes) (Fig. 6).

In terms of total population and population density, the largest civil parishes are Engure and Mērsrags, as well as Lauciene and Vandzene, where in 2010 the population ex-

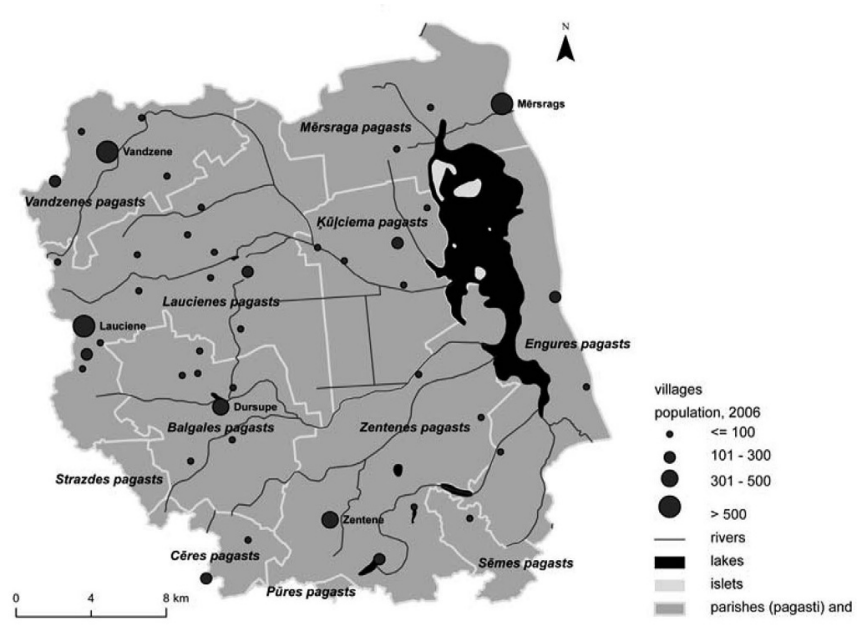

Fig. 6. Administrative division in the Lake Engure catchment area (prepared by authors using the map database GIS Latvija 9.2 (SIA Envirotech)). 
ceeded 1.8 thousand and where the population density was greater than 10 people per $\mathrm{km}^{2}$ (according to data from the population register). One of the smallest civil parishes in terms of population is Kūḷciems civil parish, which in 2010 had a population of only 500 (and a population density of 7.2 per $\mathrm{km}^{2}$ ).

Nowadays approximately 50-60\% (Balgale, Lauciene and Vandzene civil parishes) up to as many as $90 \%$ (Küụlciems, Zentene and Mērsrags civil parishes) of all civil parish residents in the Lake Engure catchment area live in villages. Most of the civil parishes have medium-sized, small and scattered villages. The proportion of the population living in the villages varies, with 2-8 up to 18-30 and more percent of the civil parish residents living in each village. Lauciene and Vandzene civil parishes have relatively large numbers of villages. In these civil parishes the number of villages exceeds 10 , these mainly being small and scattered villages (Anonīms, 2007). On the other hand, Mērsrags civil parish has only four villages, two of which are scattered (three of the villages being located within the Lake Engure catchment area).

\section{REFERENCES}

Anonīms (2001a). Kūlciema pagasts [Kūḷciems civil parish]. Grām: Latvijas pagasti. Enciklopēdija. 1. sēj. (536.-539. 1pp.). Rīga: Preses nams (in Latvian).

Anonīms (2001b). Tukuma kalendārs 2002. gadam [Tukums calendar for year 2002 ]. Neatkarīgās Tukuma Ziņas (in Latvian).

Anonīms (2002). Mērsraga pagasts [Mērsrags civil parish]. Grām: Latvijas pagasti. Enciklopēdija. 2. sēj. (67.-71. lpp.). Rīga: Preses nams (in Latvian).

Anonīms (2007). Latvijas ciemi [Villages of Latvia]. Rīga: LG̣IA. 647 lpp. (in Latvian),

Anonīms (2011). Ceḷo Talsu, Dundagas un Rojas novados [Travel about Talsi, Dundaga and Roja counties]. http://www.talsitourism.lv/ (last accessed 22.11.2011) (in Latvian).

Anonīms (2011). Centrālās statistikas pārvaldes datu bāzes. Iedzīvotāji un sociālie procesi [Databases of the Central Statistical Bureau of Latvia. Population and social processes]. http://data.csb.gov.lv/ (last accessed 04.07.2011) (in Latvian).

Anonīms (2011). Dabas parka "Engures ezers" dabas aizsardzības plāns [Nature protection plan of Nature Park "Lake Engure"]. http://www.ldf.lv/upload_file/28009/eedpdap1.doc (last accessed 04.07.2011) (in Latvian).

Anonīms (2011). Latvijas ezeru datu bāze [Lake Database of Latvia]. http://www.ezeri.lv/ (last accessed 04.07.2011) (in Latvian).

Anonīms (2011). Engures ezera dabas parks [Lake Engure Nature Park]. http://www.eedp.lv/public/ (last accessed 22.11.2011) (in Latvian).

Anonīms (2011). Engures ezers [Lake Engure].

http://www.mersrags.lv/eng_ezers.htm (last accessed 04.07.2011) (in Latvian).

Anonīms (2011). Mērsraga ostas ziṇas [News of Mērsrags Port]. http://www.mersrags.lv/Osta.htm (last accessed 21.11.2011) (in Latvian).

Anonīms (2011). Mērsrags. http://www.mersrags.lv/novads.htm (last accessed 22.11.2011) (in Latvian).

Anonīms (2011). PMLP. Statistika. Iedzīvotāju reğistrs [Office of Citizenship and Migration Affairs. Statistics. Population Register].

http://www.pmlp.gov.lv/lv/statistika/iedzivotaju.html (last accessed 04.07.2011) (in Latvian)
Andrén, T., Björck, S., Andrén, E., Conley, D., Zillén, L., Anjar, J. (2011). The development of the Baltic Sea Basin during the last $130 \mathrm{ka}$. In: The Baltic Sea Basin. Harff, J. et al. (eds.). Rostock [etc]: Springer Verlag.

Grīne, I., Strautnieks, I., Krišjāne, Z. (2011). Engures ezera baseins kā apdzīvojuma, saimniekošanas un dabas apstākḷu mijiedarbības piemērs. [Lake Engure catchment area as an example of interaction of the settlement pattern, economic activities and nature environment]. Grām.: LU 69. zinātniskā konference. Geogrāfija, geologiija, vides zinātne. Referātu tēzes (429-430. 1pp.). http://www.geo.lu.lv (last accessed 04.07.2011) (in Latvian).

Juskevičs, V. (1999) Latvijas ǵeologiskā karte. Mērogs 1 : 200 000. Lapas 42 (Jūrmala). Paskaidrojuma teksts un kartes [Geological map of Latvia. Scale 1 : 200 000. Sheet 42 (Jūrmala). Explanatory note and maps]. Rīga: Valsts ǵeoloǵijas dienests (in Latvian).

Markots, A., Strautnieks, I., Zelčs, V. (2007). Morphology, internal structure and genetic interpretation of the moraine ridge at Cêre, central part of the Northern Kursa Upland, NW Latvia. In: Quaternary of Western Lithuania: From the Pleistocene Glaciations to Evolution of the Baltic Sea. Proceedings of the International Field Symposium, May 27 - June 02 (pp. 51-52). Plateliai (Lithuania).

Mūrnieks, I. (1999). Latvijas ǵeologiskā karte. Mērogs 1 : 200 000. Lapas 42 (Jūrmala). Paskaidrojuma teksts un kartes. [Geological map of Latvia. Scale 1 : 200,000. Sheet 42 (Jūrmala). Explanatory note and maps]. Rīga, Valsts ǵeoloğijas dienests (in Latvian).

Penēze, Z., Krūze, I. (2011). Zemes izmantošana Engures ezera sateces baseinā. Grām.: LU 69. zinātniskā konference. Ģeogrāfija, ǵgeologiija, vides zinātne. Referātu tēzes [Land Use in the Lake Engure Catchment Area] (468.-469. lpp.). Rīga: LU. http://www.geo.lu.lv (last accessed 04.07.2011) (in Latvian).

Placēna, B. (1995). Engures ezers [Lake Engure]. Grām.: Latvijas daba. Enciklopēdija. 2. sēj. (50.-51. lpp.). Rīga: Latvijas enciklopēdija (in Latvian).

Rutkis, J. (1960). Latvijas ǵgeogrāfija. Stokholma: Apgāds Zemgale. 793 lpp.

Strautnieks, I. (1998). Engures līdzenums [Engure Plain]. Grām.: Latvijas daba. Enciklopēdija. 2. sēj. (51.-52. 1pp.). Rīga: Latvijas enciklopēdija (in Latvian).

Strautnieks, I. (1998). Vanemas pauguraine [Vanema Hilly Area]. Grām.: Latvijas daba. Enciklopēdija. 6. sēj. (33.-34. lpp.). Rīga: Preses nams (in Latvian).

Strautnieks, I., Zelčs, V., Markots, A., Dzelzītis, J. (2004). Stop 3: The gravel pits at Cēre. In: International Field Symposium on Quaternary Geology and Modern Terrestrial Processes, Western Latvia, September 12-17, 2004: Excursion Guide (pp. 21-24). Rīga: University of Latvia.

Veinbergs, I. (1996). Baltijas baseina attīstības vēsture leduslaikmeta beigu posmā un pēcleduslaikmetā pēc Latvijas piekrastes un tai piegulošās akvatorijas pētījumu materiāliem [History of Baltic Catchment Area Development in the Concluding period of the Ice Age and in the Postglacioal Period after Research Materials of Latvian Seashore and Its Aquatorium]. Rīga: Latvijas Universitāte, Ģeoloǵijas institūts. 123 lpp. (in Latvian).

Vīksne, J. (1995). Engures ezera ornitoloğiskais liegums [Ornithological restricted area of Lake Engure]. Grām.: Latvijas daba. Enciklopēdija. 2. sēj. (50. 1pp.). Rīga: Latvijas enciklopēdija (in Latvian).

Zelčs, V. (1998). Dundagas pacēlums [Dundaga Rise]. Grām.: Latvijas daba. Enciklopēdija. 2. sēj. (14.-15. lpp.) Rīga: Latvijas enciklopēdija (in Latvian).

Zelčs, V., Markots, A. (2004). Deglaciation history of Latvia. In: Extent and Chronology of Glaciations (pp. 225-244). Ehlers, J., Gibbard, P.L. (eds.). Elsevier.

Аболтиньш О.П. (1989). Гляциоструктура и ледниковый морфогенез [Glaciostructure and glacier morphogenesis]. Рига: Зинатне, 284 с. (in Russian).

Вейнбергс И. (1968). Морфогенез рельефа Западной Латвии во время последнего оледенения и особенности развития основных рельефообразуюших процессов. Диссертация [Relief morphogenesis of West 
part of Latvia at the time of last glaciation and the specific character of the development of relief formation processes. Thesis]. Рига. 366 c. (in Russian).

Received 9 January 2012
Гринбергс Э.Ф. (1957). Позднеледниковая и послеледниковая история побережья Латвийской ССР [Late-glacier and Post-glacier History of the Coastal Zone of the Latvian SSR]. Рига. (in Russian)

Страуме Я.А. (1979). Геоморфология [Geomorphology]. В кн: Геологическое строение и полезные ископаемые Латвии (с. 297-439). Рига: Зинатне (in Russian).

\section{ENGURES EZERA BASEINS KĀ DABAS APSTĀKLUU, APDZĪVOJUMA UN SAIMNIEKOŠANAS MIJIEDARBĪBAS PIEMĒRS}

Raksts veidots kā apskatraksts par teritoriju, kurā ietverti publicētie dati, kā arī jauna, oriǵināla pētījuma rezultāti. Tajā atspoguḷotas ǵeoloğiskās uzbūves īpatnības, ietverot subkvartāra virsmas iežu raksturojumu un subkvartāra virsmas reljefu. Sīkāk raksturota kvartārnogulumu sega un virsmas reljefs, uzsverot arī to ǵenēzes apstākḷus, arī hipsometrija, kam daudzviet ir tieša ietekme uz virsmas noteces apstākḷiem, augšnu veidošanos un ainavas īpatnībām. Pamatojoties uz reljefa morfoloǵijas un iekšejjās uzbūves īpatnībām, ieskicēti arī galvenie reljefa veidošanās etapi, kas faktiski iezīmē arī neviendabību ainavu attīstībā laika ziṇā. Augstāk minēto faktoru, kā arī virknes citu dabas apstākḷu (pazemes ūdeṇu, virszemes ūdeṇu, jūras tuvuma) ietekme lokāli atškirīgās teritorijas daḷās izskaidro cilvēku saimniekošanas virzienus, apdzīvojuma veidošanos, kā arī gadsimtu gaitā saglabājušās tradīcijas. Teritorijāa labi iezīmējas pēc funkcionalitātes vairāki atšḳirīgi areāli: 1) raksturīga nodarbošanās ar lauksaimniecību, 2) zvejniecība un rekreācija, 3) mežu teritorijas, kur augsnes nav piemērotas lauksaimniecībai. Saimniekošanas veids un intensitāte nosaka arī apdzīvoto vietu teritoriālo izvietojumu un iedzīvotāju skaitu. 